\title{
Effect of some rhizosphere bacteria on root-knot nematodes
}

\author{
Ghena Mamdouh AbdelRazek ${ }^{1}$ and Rabaa Yaseen ${ }^{2^{*}}$
}

\begin{abstract}
Background: Root-knot nematodes are among the world's most damaging endoparasitic sedentary nematodes, especially, Meloidogyne incognita that infects a wide range of plant hosts. The activity of different antagonistic bacteria was studied for the low-cost and eco-friendly management of $M$. incognita on eggplant.

Main body: Twenty-five isolates were isolated from rhizosphere soils infected with nematodes. Of these, 6 isolates displayed the highest activity, demonstrating 100\% mortality of J2 nematodes under laboratory conditions. Partial sequencing of 165 rRNA gene and phylogenetic analysis was used to identify the selected isolates and they were found to be Paenibacillus amylolyticus, Brevibacillus agri, Gluconobacter frateurii, Beijerinckia mobilis, Achromobacter aloeverae, and Pseudomonas stutzeri. The abilities of the selected isolates to produce hydrogen cyanide, siderophores, chitinase, protease, indole acetic acid, and to dissolve phosphorus were also detected.

Conclusion: The results of the greenhouse experiment indicated that all the tested bacteria had a greatly significant effectiveness for suppressing root-knot nematode $M$. incognita. Application of all the rhizosphere bacteria and their combinations reduced the number of galls, number of juveniles, egg-masses, eggs, females, and total final population. All bio-agent treatments succeeded in improving the plant growth parameters and increased the microbial density in eggplant rhizosphere.
\end{abstract}

Keywords: Nematicidal activity, Meloidogyne incognita, PGPR, Biological control, Hydrolytic enzymes, Eggplant

\section{Background}

Root-knot nematodes are among the world's most damaging endoparasitic sedentary nematodes (Trudgill and Blok 2001). The different species in this genus have an overall host range encompassing around 5500 species of plants. Of the root-knot nematodes, Meloidogyne species are known to be the most extensively distributed in tropical and subtropical countries on a large range of plant hosts including crop and vegetable seeds, ornamentals, fruit trees, and weeds (Luc et al. 2005). Bakr et al. (2011) pointed out that root-knot nematodes are one of the most crop productions limiting factor in Egypt, and the incidence of the root-knot disease caused

\footnotetext{
* Correspondence: rabaa.yaseen@yahoo.com

${ }^{2}$ Fertility and Soil Microbiology Department, Water Resources and Desert Soils Division, Desert Research Center, El-Matariya, Cairo 11753, Egypt Full list of author information is available at the end of the article
}

by Meloidogyne spp. was the greatest in sandy soil, especially in newly reclaimed areas.

Eggplant (Solanum melongena L.) is one of the world's most popular grown vegetable crops. In Egypt, eggplant is known to be extremely susceptible to infection with rootknot nematode (Abd-Elgawad 2014). This may raise the vulnerability of the crop to certain wild diseases such as bacterial and fungal wilt (Tharshani and Sivapalan 2009).

Management of plant-parasitic nematodes is more difficult than the management of other pests because nematodes mostly inhabit the soil and usually attack the plant roots (Nicol 2002). Although the application of chemical nematicides is successful, simple, and has rapid results, in some developing countries, they have started to withdraw from the market due to concerns regarding public health and environmental protection (Schneider et al. 2003). Hence, the quest for a new, environmentally sustainable alternative agent to control populations of 
plant-parasitic nematodes has become extremely relevant. Biological control is made more common because of its harmony with the climate and its non-toxic existence (Jiang et al. 2014). The use of such eco-friendly microorganisms helps to keep environmental integrity and attain a pollution-free environment. Bio-agent stays successful in soil for long periods of time after formation, which in due course contributes to the principle of suppressive soils (Trudgill and Blok 2001). While biological control of plant-parasitic nematodes is still under research and discovery. Consequently, for more efficient biological control against root-knot nematodes, different strains of antagonistic bacteria are very much needed.

Biological control of nematodes can be achieved mainly by antagonists of the fungi and bacteria. The nematodes-fungal antagonists consist of a variety of fungal spp. which includes endo-parasitic fungi, nematodetrapping fungi, toxin-producing fungi, parasites of sedentary nematodes, and vesicular-arbuscular mycorrhiza (Timper 2014). Whereas the bacterial antagonists consist of mainly three groups, viz., epiphytic, endophytic, and endoparasitic bacteria. Bacteria attain biological control by mechanisms such as antibiosis, competition, and parasitism (Abd-Elgawad and Kabeil 2012); siderophores produced by bacteria can also act as an induced systemic resistance (ISR) determinant in plants (Lucas et al. 2014). Another mechanism for biocontrol may be the production of hydrolytic enzymes such as chitinase and protease (Vaidya et al. 2001).

Accordingly, the present research aimed to examine the behavior of different antagonistic bacteria for lowcost and environmentally sustainable control of plant parasite root-knot nematodes $M$. incognita in eggplant in vitro and under greenhouse conditions.

\section{Materials and methods Isolation of bio-agent}

Different bacterial isolates were isolated from rhizosphere soil of plants infected with root-knot nematodes. The rhizosphere soil was obtained from North Sinai and Cairo Governorates, Egypt. The isolation was carried out on a nutrient agar (NA) medium. Colonies were recovered and purified by successive streaking on the NA medium. Cultures were maintained in the NA medium and stored in $20 \%$ glycerol at $-20^{\circ} \mathrm{C}$.

\section{Preparation of nematode inoculum}

To initiate and propagate pure stock culture of the rootknot nematode, M. incognita (Kofoid and White) Chitwood, galled roots of highly infected eggplants (Solanum melongena) were collected. Single egg mass was used to inoculate eggplants grown under greenhouse conditions. The identification of females' perennial pattern was done according to Taylor et al. (1955). Two months later, re- inoculation on new seedling of eggplants continuously was carried out for preparing pure egg mass culture of $M$. incognita. The eggs and nematode J2s were used for all the subsequent tests.

\section{Effect of bacterial isolates and their supernatants on mortality percentages of $M$. incognita J2}

Bacterial isolates were screened for their abilities to inhibit the second juvenile (J2) of M. incognita. Mortality percentage was calculated according to the method described by Schneider and Orelli (1947). For mortality test, $2 \mathrm{ml}$ of freshly hatched J2s of M. incognita, containing $100 \pm 10$ juveniles/ml was placed in each Petri dish and $2 \mathrm{ml}$ of bacterial culture from each bacterial isolate containing $2 \times 10^{8}(\mathrm{cfu} / \mathrm{ml})$ was added separately. Petri dish with nematodes and without culture served as control. All dishes were incubated in an incubator at $25 \pm$ $2{ }^{\circ} \mathrm{C}$. The supernatant of 6 bacterial isolates with highly suppressive effect against $M$. incognita were evaluated for their activity against $M$. incognita as previously described. After $48 \mathrm{~h}$, the J2s were counted for mortality and non-mortality under stereoscope. The mortality of nematodes was confirmed by keeping them in tap water for $24 \mathrm{~h}$. Nematodes were considered dead if they did not respond to being touched by a small probe. The percentage of mortality was calculated from an average of 3 replicate. After exposure periods, J2s were washed, using distilled water then transferred to clean Petri dishes for $24 \mathrm{~h}$ to ensure that no recovery will be occurred. The percentage of nematode mortality was calculated according to Abbott's formula (Abbott 1925).

Juvenile mortality $\%=\frac{T-C}{100-C} \times 100$

Where $T$ is \% of nematode mortality in the treatment and $C$ is \% of nematode mortality in the control.

\section{Identification of the potent isolates}

The methods described by Gordon et al. (1973) were used to conduct cellular morphology and biochemical tests. Young bacterial cultures $(24 \mathrm{~h})$ were used to display the cellular motility. Isolates were identified by direct extraction of genomic DNA from the colonies grown on NA medium and was used as template for PCR by using forward and reverse primers, F (5' AGA GTT TGA TCC TGG CTC AG-3') and R (5'-GGT TAC CTT GTT ACG ACTT-3'), according to the modified method of Ishikawa et al. (2000). The selected isolates were sequenced, using $16 \mathrm{~S}$ rRNA sequencing and assembled in the BioEdit software (Hall 1999). The phylogenetic tree was constructed, using the neighbor-joining NJ method (Saitou and Nei 1987). 


\section{Characterization of nematicidal traits of the selected isolates}

The selected bacterial isolates which showed considerable mortality percentage for $M$. incognita were investigated for the following traits.

\section{Hydrogen cyanide production}

The potential of bacterial isolates to produce $\mathrm{HCN}$ qualitatively was assessed according to Bakker and Schipper (1987). Nutrient agar slants contained 0.44\% glycine were streaked by selected bioagent bacteria. A strip of sterile filter paper that had previously been soaked in a solution of $0.5 \%$ picric acid and $2 \% \mathrm{Na}_{2} \mathrm{CO}_{3}$ was added inside the NA slants and sealed with parafilm. The inoculated slants were incubated at $28^{\circ} \mathrm{C}$ for $48 \mathrm{~h}$. The change in filter paper color from yellow to brown was verified as a positive reaction.

\section{Siderophores production}

Production of siderophores was determined by Reeves et al. (1983) method. Selected isolates were grown in nutrient broth at $28{ }^{\circ} \mathrm{C}$ for 3 days and cultures supernatant was collected by centrifugation (6000 rpm, $20 \mathrm{~min})$. The $\mathrm{pH}$ was adjusted to 2.0 with diluted $\mathrm{HCl}$ and in a separating funnel equal quantity of ethyl acetate was added, and mixed well, then ethyl acetate fraction was collected. This process was repeated 3 times to extract the entire quantity of siderophore from the supernatant. Five milliliters of Hathway's reagent $(1.0 \mathrm{ml}$ of $0.1 \mathrm{M}$ FeC13in $0.1 \mathrm{~N}$ HC1 to $100 \mathrm{ml}$ distilled water $+1.0 \mathrm{ml}$ of $0.1 \mathrm{M}$ potassium ferricyanide) was added to $5 \mathrm{ml}$ of the ethyl acetate fraction and shaken thoroughly. The absorbance was measured at $700 \mathrm{~nm}$ for dihydroxy phenols using a standard curve prepared with dihydroxy benzoic acid and the quantity of siderophore produced was expressed as $\mu \mathrm{g} / \mathrm{ml}$.

\section{Chitinase production \\ Colloidal chitin preparation}

Colloidal chitin was prepared according to Murthy and Bleakley (2012). In brief, $20 \mathrm{~g}$ of crab shell powder was suspended in $150 \mathrm{ml}$ of concentrated $\mathrm{HCl}$ for $60 \mathrm{~min}$ at room temperature. Then $2 \mathrm{~L}$ of distilled $\mathrm{H}_{2} \mathrm{O}$ was slowly added and left for $24 \mathrm{~h}$ at $4{ }^{\circ} \mathrm{C}$. After centrifugation, the pellet was collected and washed several times with distilled water. The $\mathrm{pH}$ of the obtained colloidal chitin was adjusted to 7 and stored at $4{ }^{\circ} \mathrm{C}$.

\section{Total chitinolytic activity}

Chitinase activity was assayed by measuring the release of reducing saccharides from colloidal chitin according to Wang and Chang (1997) with minor modification. The selected isolates were inoculated into the colloidal chitin broth medium, composed of (in g/l) $\mathrm{K}_{2} \mathrm{HPO}_{4}, 0.7$; $\mathrm{KH}_{2} \mathrm{PO}_{4}, 0.3 ; \mathrm{MgSO}_{4} .5 \mathrm{H}_{2} \mathrm{O}, 0.5 ;\left(\mathrm{NH}_{4}\right) 2 \mathrm{SO}_{4}$; colloidal chitin 20; and $\mathrm{pH} 7.0$ and were incubated for 5 days at $30{ }^{\circ} \mathrm{C}$. One milliliter of cultures supernatant was mixed by $0.5 \mathrm{ml}$ of $1 \%$ solution of dinitrosalicylic acid and heated at $100{ }^{\circ} \mathrm{C}$ for $5 \mathrm{~min}$. Absorbance of the reaction mixture was measured at $582 \mathrm{~nm}$ after cooling to room temperature. One unit of the chitinase activity was defined as the amount of enzyme, which yields $1 \mu \mathrm{mol}$ of reducing sugar as $\mathrm{N}$-acetyl-d-glucosamine equivalent per minute.

\section{Protease production}

Protease activity of the cultures supernatants of the selected isolates was measured according to the techniques described by Pokhrel et al. (2014), with slight modifications. In brief, $1 \mathrm{ml}$ of each supernatant was incubated with $0.1 \mathrm{M}$ phosphate buffer ( $\mathrm{pH} 7.0$ ) and $2 \mathrm{ml} 1 \%$ casein solution at $50{ }^{\circ} \mathrm{C}$ for $2 \mathrm{~h}$. The reaction was stopped by the addition of $3 \mathrm{ml}$ trichloroacetic acid and subsequent centrifugation, $1 \mathrm{ml}$ of this solution was mixed with 2.5 $\mathrm{ml}$ of $0.5 \mathrm{M}$ sodium carbonate and incubated at room temperature for $30 \mathrm{~min}$. One milliliter of Folin phenol reagent was added and incubated again for $15 \mathrm{~min}$ at room temperature before being measured at $660 \mathrm{~nm}$. One unit of enzyme activity was defined as the amount of enzyme needed to release $1 \mu \mathrm{mol}$ of tyrosine per min.

\section{Determination of plant growth-promoting activities Indole-3-acetic acid production}

The selected bacterial isolates were screened for their ability to produce IAA according to the method used by Apine and Jadhav (2011). Bacterial isolates were grown on nutrient broth medium $(0.5 \%$ yeast extract, $1 \%$ peptone, $0.5 \% \mathrm{NaCl}, \mathrm{pH} 7.2)$ supplemented with $0.1 \%$ L-tryptophan and incubated at $30^{\circ} \mathrm{C}$ for $48 \mathrm{~h}$. After incubation, culture supernatants were collected by centrifugation at $8000 \times g$ for $15 \mathrm{~min}$. Two milliliters of supernatant were mixed with $2 \mathrm{ml}$ of Salkowski reagent $(1 \mathrm{ml}$ of $0.5 \mathrm{M}$ $\mathrm{FeCl}_{3}$ in $49 \mathrm{ml}$ of $35 \%(\mathrm{w} / \mathrm{v}) \mathrm{HClO}_{4}$ ) and incubated for $30 \mathrm{~min}$ at room temperature. Occurrence of a pink color confirmed IAA production. Optical density was read at wavelength of $530 \mathrm{~nm}$, and the standard curve was prepared with pure IAA (Merck, Germany) to estimate the IAA concentration.

\section{Inorganic phosphate solubilization}

Phosphate solubilization ability was investigated according to Liu et al. (2014). Pure cultures were inoculated in a liquid Pikovskaya medium. The liquid cultures were centrifuged and soluble phosphate in the supernatants was determined by the molybdenum blue colorimetric method (Watanabe and Olsen 1965).

\section{Greenhouse experiment}

The experiment was conducted at the experimental greenhouse of Nematodes Research Unit, Plant Protection 
Department Desert Research Center, Cairo, Egypt. The most active anti-nematodes bacterial isolates in the in vitro test were cultured on nutrient broth medium. The bacterial mass was harvested via centrifugation and further suspended in saline buffer. Each isolate was then arranged by spectrophotometry to $10^{8} \mathrm{cfu} / \mathrm{ml}$ at a wavelength of $600 \mathrm{~nm}$ prior to greenhouse tests. The bacterial inocula were applied as a soil treatment at the rate of $15 \mathrm{ml}$ of bacterial suspension per plant. The commercial bionematicide, Micronema, was applied as a soil drench at recommended rates $(6 \mathrm{~cm} / \mathrm{l})$ and the chemical nematicide, Mocap (15\% w/w ethoprophos; Bayer Crop Science, UK) was applied at rate of $2 \mathrm{~g}$ per pot. Untreated infected plants served as positive control and untreated uninfected plants served as negative control. Four-week-old eggplant seedlings cultivar Baladi, with uniform size were transplanted singly in $15 \mathrm{~cm}$ clay pots filled with mixture of autoclaved clay and sand soil (1:2, v/v). After 7 days, plants were treated by the bacterial suspension. Ten-day-old plants were inoculated with 2000 freshly hatched second stage (J2) of $M$. incognita by making 3 holes at different depths $(2-3 \mathrm{~cm})$ around the roots. After 15 days of infection, the previously microbial inoculants were re-added at the same rate. All plants received $1 \mathrm{~g}$ NPK (19-19-19) every 2 weeks. Pots were watered periodically every 3 days and kept at $35^{\circ} \mathrm{C} \pm 2{ }^{\circ} \mathrm{C}$ in complete randomized design.

\section{Reduction percentage in nematode enumeration and plant growth parameters determination}

Two months post-inoculation time, plants were uprooted and soil of each pot was processed for nematode extraction by sieving according to Baerman pan technique (Southey 1970). Counts of J2 in soil of each pot were determined by means of Hawksley counting slide and stereoscope. Galls and egg masses were counted, and their indices were recorded according to Sharma et al. (1994). The average numbers of eggs/egg masses were determined by rinsing four randomize selected egg masses per root system of each replicate in $1 \%$ sodium hypochlorite to emerge eggs from egg matrix, then the emerged eggs were suspended in water and counted under a stereoscope. The reduction percentage in galls formation, egg-masses production, also female's numbers and J2s numbers were also calculated. The final population (FP) was calculated for all treatments by summation of the number of J2s in soil, egg masses, and females. The reproduction rate of nematode was calculated by dividing the nematode final population on the nematode initial population according to Norton (1978). Plant growth response based on shoot length, fresh, and dry weights as well as root fresh weight and length were determined for all treatments. Total microbial counts in soil rhizosphere were carried out using the decimal count technique.

\section{Statistical analysis}

For the statistical analysis of the results, the data on the experiments were subjected to analysis of variance (ANOVA), and means were separated $(p \leq 0.01)$ by Duncan's multiple range test using the Statistical Analysis Software (SAS-9.4, SAS Institute Taiwan Ltd, Taipei, Taiwan).

\section{Results and discussion}

\section{Isolation and screening of bacterial agents with} nematicidal properties

A total of 25 bacterial isolates were isolated from the rhizosphere of nematode-infested soils in North Sinai, Cairo Governorates, Egypt. Locations of soil samples, infected plants, and number of isolated bacteria are represented in Table 1. Obtained isolates were tested for their potential to inhibit the J2 of $M$. incognita in vitro tests. Obtained results, after $48 \mathrm{~h}$ of exposure, revealed that all bacterial cultures caused mortality (significant at $p<$ 0.05 ) in $M$. incognita J2. The percentage of mortality ranged between 44 and $100 \%$. Isolates numbered as RF5, RG9, RG10, BO16, BO17, and BB19 exhibited the highest percentage $(100 \%)$ of mortality, followed by RT14 and BG8 that recorded 93 and $88.3 \%$, respectively. The lowest were obtained from the isolates BP23, BB18, RF7, and RG11, which recorded $44,45,46.3$, and $46.3 \%$, respectively (Fig. 1). The bacterial culture supernatants of the 6 selected bacterial isolates were examined for their nematicidal activities in vitro tests. Obtained results after $48 \mathrm{~h}$ of exposure, revealed that all culture filtrates caused mortality to $M$. incognita J2 (Fig. 2). The supernatant of isolate RG10 exhibited the highest mortality rate (100\%), followed by BB19 (98\%). The lowest mortality rate (89.33\%) was obtained by the RG9 culture supernatant. There are different species capable of antagonizing the plant-parasitic root-knot nematode. The term "antagonist" is used to describe a number of microorganisms including frequent enemies such as parasitoids and predators and even microorganisms that develop extracellular hydrolytic enzymes, antibiotics, or cause systemic plant resistance (Timper 2014).

Table 1 Isolation of bacterial agents

\begin{tabular}{lll}
\hline Location & Infected plant & Isolate number \\
\hline Rommana & Olive & RO1, RO2, RO3 \\
Rommana & Figs & RF4, RF5, RF6, RF7 \\
Rommana & Grape & RG8, RG9, RG10, RG11 \\
Rommana & Tomato & RT12, RT13, RT14 \\
Baloza & Olive & BO15, BO16, BO17 \\
Baloza & Bean & BB18, BB19, BB20, BB21, BB22 \\
Baloza & pepper & BP23, BP24, BP25 \\
\hline
\end{tabular}




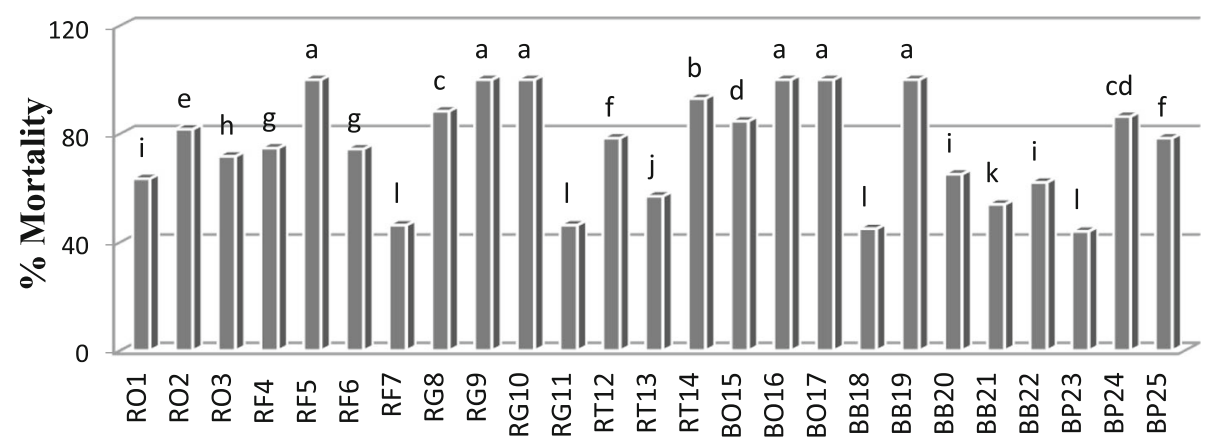

Bacterial isolates

Fig. 1 Nematicidal activity of isolated bacteria on Meloidogyne incognita juvenile mortality after $48 \mathrm{~h}$. LSD at 0.05 is 2.63

\section{Identification of the selected isolates and phylogenetic analysis}

Morphological and biochemical characteristics of the selected isolates are summarized in Table 2. The isolates RF5 and RG9 were Gram positive, whereas isolates RG10, BO16, BO17, and BB19 were Gram negative. All isolates were rod-shaped and motile and showed positive reactions for catalase, gelatin liquefaction, and casein hydrolysis and a negative reaction for the urease test. The 16S rRNA nucleotide sequence revealed that the selected isolates were closely related to Paenibacillus amylolyticus, Brevibacillus agri, Gluconobacter frateurii, Beijerinckia mobilis, Achromobacter aloeverae, and Pseudomonas stutzeri with blast identity of 99, 98, 99, 97,95 , and $98 \%$, respectively and $100 \%$ of query average. Phylogenetic tree of the 6 bacterial strains and closely correlated strains was illustrated in Fig. 3.

\section{Characterization of nematicidal and plant growth- promoting traits of the selected isolates}

The applied bacteria were tested for the production of $\mathrm{HCN}$ and siderophores. Pseudomonas stutzeri demonstrated a strong capability of producing $\mathrm{HCN}$, while the rest did not. As for the development of siderophores, the most productive isolate was G. frateurii $(64.6 \mu \mathrm{g} / \mathrm{ml})$, followed by $P$. stutzeri and $P$. amylolyticus (46.4 and $41.2 \mu \mathrm{g} / \mathrm{ml}$, respectively). No siderophores were detected by the 3 other bacteria as shown in Table 3 . The six isolates were also checked for quantitative test of extracellular chitinase and protease in liquid medium. Data presented in Table 3 revealed that the chitinase production varied from 27 to $51.1 \mathrm{U} / \mathrm{ml}$, the maximum production being observed for the isolate G. frateurii $(51.1 \mathrm{U} / \mathrm{ml})$ and $A$. aloeverae $(48 \mathrm{U} / \mathrm{ml})$, while the lowest was observed for the isolate $B$. mobilis $(27 \mathrm{U} / \mathrm{ml})$. All the selected isolates secreted protease enzyme at varied levels. The maximum protease activity $(388.61 \mathrm{U} / \mathrm{ml})$ was attained by $G$. frateurii followed by $P$. amylolyticus $(306.91 \mathrm{U} / \mathrm{ml})$ and $P$. stutzeri $(297.66 \mathrm{U} / \mathrm{ml})$, whereas the lowest enzyme activity was observed by $A$. aloeverae and $B$. mobilis with enzyme activity $(160.51$ and $205.74 \mathrm{U} / \mathrm{ml}$ ), respectively.

All the 6 tested bacterial isolates produced IAA in culture broth; the amount, however, varied significantly

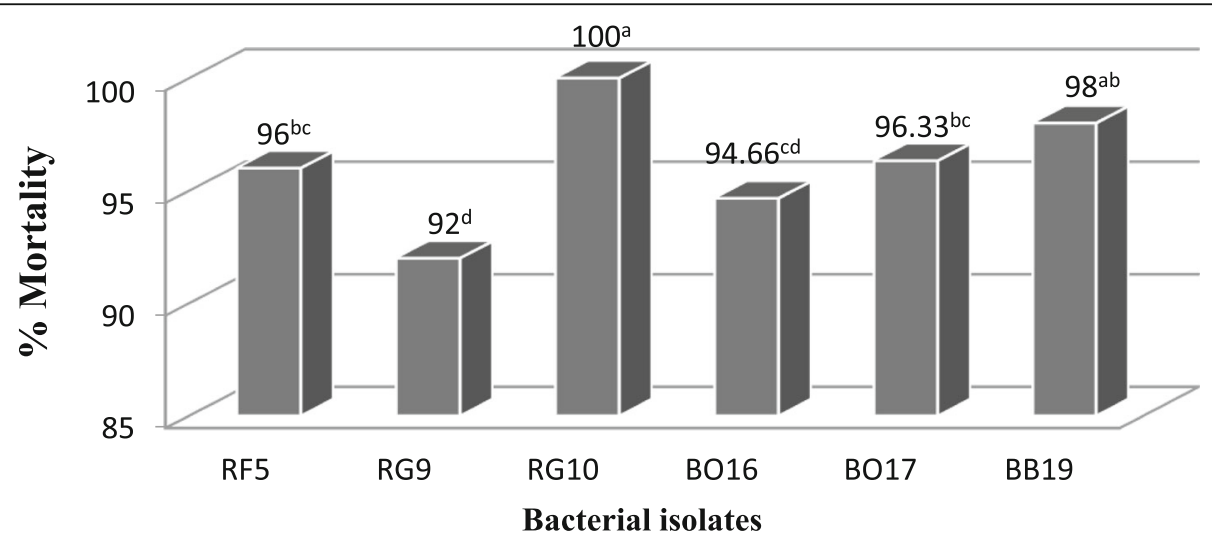

Fig. 2 Nematicidal activity of the selected bacterial culture filtrate on Meloidogyne incognita juvenile mortality after 48 h. LSD at 0.05 is 2.87 
Table 2 Morphological and biochemical properties of the selected isolates

\begin{tabular}{|c|c|c|c|c|c|c|}
\hline \multirow[t]{2}{*}{ Characteristic } & \multicolumn{6}{|c|}{ Bacterial isolate } \\
\hline & RF5 & RG9 & RG10 & B016 & B017 & BB19 \\
\hline Colony color & Translucent & Translucent & Creamy & White & Translucent & Light brown \\
\hline Gram staining & + ve & +ve & -ve & $-v e$ & $-v e$ & $-v e$ \\
\hline Shape & Rod & Rod & Rod & Rod & Rod & Rod \\
\hline Motility test & + & + & + & + & + & + \\
\hline Spore forming & + & + & - & - & - & - \\
\hline Methyl red test & + & + & + & - & - & + \\
\hline Oxidase test & + & - & - & + & + & + \\
\hline Catalase test & + & + & + & + & + & + \\
\hline Arginie dihydrolysis & - & - & - & + & - & - \\
\hline Starch hydrolysis & + & - & - & - & - & + \\
\hline Gelatin liquefaction & + & + & + & + & + & + \\
\hline Casein hydrolysis & + & + & + & + & + & + \\
\hline $\mathrm{H}_{2} \mathrm{~S}$ production & - & - & + & - & - & + \\
\hline Urease & - & - & - & - & - & - \\
\hline Voges-Proskauer test & - & - & - & - & - & + \\
\hline
\end{tabular}

among the strains and the order was G. frateurii $>P$. stutzeri $>$ P. amylolyticus $>$ B. mobilis $>$ A. aloeverae $>$ $B$. agri. Almost all isolates were able to dissolve phosphorus in the culture. The greatest solubilization was induced by $P$. stutzeri $(25.9 \mu \mathrm{g} / \mathrm{ml})$, followed by G. frateurii $(22.5 \mu \mathrm{g} / \mathrm{ml})$, and the least was induced by $A$. aloeverae $(13.6 \mu \mathrm{g} / \mathrm{ml})$. Brevibacillus agri had no ability to dissolve phosphorus in culture broth (Table 3). One of the most promising alternate control methods for chemical nematicides is the application of antagonistic microorganisms, particularly those that generate lytic enzymes. Batool et al. (2013) reported that $P$. aeruginosa caused more than $90 \%$ mortality in in vitro tests, performed with $M$. javanica, due to the high secretion of chitinase. Also, Cetintas et al. (2018) reported that Paenibacillus castaneae and Mycobacterium immunogenum were effective biocontrol agents for the management of the nematode $M$. incognita. They added that proteases and chitinases play an important role in the degradation of the nematode cuticle and serve as nematicidal factors for biocontrol of nematode populations. Production of secondary metabolites, including siderophores, protease, $\mathrm{HCN}$, and chitinase by $P$. fluorescens and $P$. putida, induce mortality in wheat cyst nematode Heterodera avenae and inhibited egg hatching as reported by Ahmed (2017). According to Tran et al. (2019), the antinematode, Bacillus megaterium strain showed a good effect on promoting pepper growth against Meloidogyne sp. through its enzymatic activities, including chitinase and protease activity. Also, Soliman et al. (2019) reported that $P$. aeruginosa, $P$. polymyxa, Lysinibacillus sphaericus, B. cereus, B. subtilis, and A. xylosoxidans produced a high yield of chitinase, chitosanase, and protease exhibited in vitro antagonism against $M$. incognita.

\section{In vivo evaluation of the nematicidal activity of the selected isolates against $M$. incognita}

Data recorded under in vivo studies (Table 4) showed that the application of all bioagent treatments ( $P$. amylolyticus, B. agri, G. frateurii, B. mobilis, A. aloeverae, $P$. stutzeri and their mixture) suppressed the total numbers of $M$. incognita on eggplant in comparison to the nematicide, Mocap 15\% (Ethoprophos) and Micronema. The reduction percentages of $\mathrm{J} 2 \mathrm{~s}$, galls, females, egg masses, eggs per egg mass, the final populations, and nematode rates of build-up that occurred with all treatments were diminished compared to control treatment. The greatest reduction percentage of $\mathrm{J} 2 \mathrm{~s}$ was obtained from $P$. stutzeri (78.21\%), and mixture of bacterial bioagent treatments (77.12\%), while the least was in case of B. agri (55.4\%) and $P$. amylolyticus (72.02\%). Also, treatments of $A$. aloeverae gave the most effect in galls, females, eggs/egg mass reduction where they caused the reduction of $82.66,80.28$, and $69.20 \%$, respectively. As well as G. frateurii recorded the most effective egg masses, final population, and rate of build-up giving 86.04, 77.75, and 1.23 , respectively. The lowest females' reduction percentages were registered by $P$. amylolyticus (66\%), while, $B$. agri recorded the lowest final population reduction percentage (56.77\%), followed by P. amylolyticus (71.17\%). The root-knot nematodes, Meloidogyne species, are the 

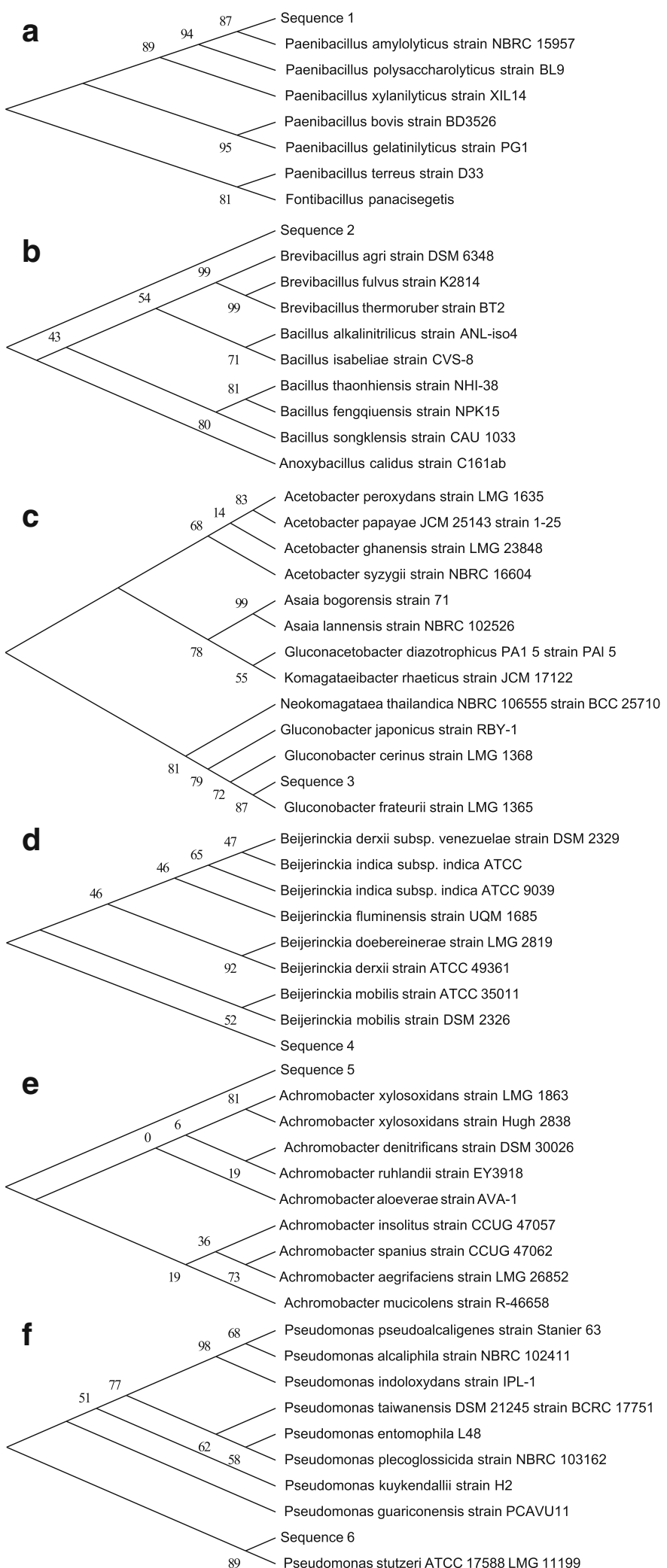

Fig. 3 Phylogenetic tree of partial 16S rRNA sequence for isolate (a) RF5, (b) RG9, (c) RG10, (d) BO16, (e) BO17, and (f) BB19. The scale bar represented $10 \%$ nucleotide substitutions. Percentages of bootstrap values recovered from 1000 trees are presented on the nodes 
Table 3 Plant growth-promoting traits of the selected isolates

\begin{tabular}{lllllll}
\hline Characteristic & \multicolumn{2}{l}{ Bacterial isolate } & & \\
\cline { 2 - 6 } & $\begin{array}{l}\text { Paenibacillus } \\
\text { amylolyticus }\end{array}$ & Brevibacillus agri & $\begin{array}{l}\text { Gluconobacter } \\
\text { frateurii }\end{array}$ & $\begin{array}{l}\text { Beijerinckia } \\
\text { mobilis }\end{array}$ & $\begin{array}{l}\text { Achromobacter } \\
\text { aloeverae }\end{array}$ & $\begin{array}{l}\text { Pseudomonas } \\
\text { stutzeri }\end{array}$ \\
\hline HCN production & - & - & - & - & - & + \\
Siderophore production $(\mu \mathrm{g} / \mathrm{ml})$ & 41.2 & - & 64.6 & - & - & 43.4 \\
Chitenase production $(\mathrm{U} / \mathrm{ml})$ & 37.4 & 33.4 & 51.1 & 27.0 & 48.0 & 45.0 \\
Protease production $(\mathrm{U} / \mathrm{ml})$ & 306.91 & 282.58 & 388.61 & 205.74 & 160.51 & 297.66 \\
IAA production $(\mu \mathrm{g} / \mathrm{ml})$ & 1.7 & 1.2 & 2.4 & 1.6 & 1.5 & 1.9 \\
Phosphate dissolving $(\mu \mathrm{g} / \mathrm{ml})$ & 15.7 & - & 22.5 & 19.2 & 13.6 & 25.9 \\
\hline
\end{tabular}

Each reported value is the mean of triplicate samples

most important group of plant-parasitic nematodes occurring worldwide (Moens and Perry 2009). They could rapidly establish feeding sites when found around plant roots, by inducing specific developmental pathways to suppress plant defense (Gheysen and Mitchum 2019). The eggs and second stage developmental stages are the most susceptible stages of plant-parasitic nematodes to be controlled through biological control. These life stages exist on soil particles outside of the plant in the surrounded water film (hygroscopic water), which enables the antagonistic micro-organisms to come into contact, infect, and parasitize the nematodes. When these two stages of the plant-parasitic nematodes are managed, the nematodes' life cycle would be disrupted and the nematode's population density would be decreased, resulting in an effective management (Allen 2004).

\section{Effect of biocontrol agent on eggplant growth}

The effect of biocontrol agents on the growth of eggplant infected with $M$. incognita was recorded in Table 5. All the treatments improved the plant growth parameters than the control. The treatment of G. frateurii gave the highest increase in shoot length (38.15\%), shoot fresh weight (169.7\%), and shoot dry weight (220.9\%), whereas the treatment of $P$. amylolyticus gave the highest increase in shoot length (36.42), followed by $A$. aloeverae (31.72\%). Pseudomonas stutzeri recorded the highest increase in shoot fresh weight (153.56\%), followed by $A$. aloeverae (144.05\%) as well as the treatment of mixture of bacteria recorded (170.9\%) increase in shoot dry weight, followed by treatments of $P$. amylolyticus and P. stutzeri recorded (163.63\%). Also, variable responses of root growth parameters were also detected. In general, all treatments of the tested agent as well as Micronema caused remarkable increase in plant growth parameters. While the application of nematicide, mocap (Ethoprophos) significantly decreased all measured plant parameters when compared to control. These results agree with that of El-Eslamboly et al. (2019). Applied bioagent could not only promote plant growth but also improve fruit quality by increasing nutrient contents such as carbohydrate, protein, and vitamin (Rashid et al. 2016).

Table 4 Effect of the selected bacterial isolates on development and multiplication of Meloidogyne incognita infecting eggplant

\begin{tabular}{|c|c|c|c|c|c|c|c|}
\hline Treatments & Galls/root & In soil & Egg masses/root & Eggs/egg mass & Females & FP & RB \\
\hline Paenibacillus amylolyticus & $367^{e}$ & $2657^{f}$ & $227^{9^{f}}$ & $351^{\mathrm{fg}}$ & $302^{e}$ & $3186^{f}$ & 1.59 \\
\hline Brevibacillus agri & $389^{e}$ & $4243^{9}$ & $215^{\text {ef }}$ & $278^{c}$ & $343^{f}$ & $4801^{9}$ & 2.40 \\
\hline Gluconobacter frateurii & $223^{b}$ & $2190^{c}$ & $95^{\mathrm{b}}$ & $207^{b}$ & $186^{c}$ & $2471^{b}$ & 1.23 \\
\hline Beijerinkia mobilis & $320^{d}$ & $2540^{e}$ & $233^{9}$ & $338^{e f}$ & $260^{d}$ & $3033^{e}$ & 1.51 \\
\hline Achromobacter aloeverae & $211^{b}$ & $2413^{d}$ & $165^{d}$ & $222^{b}$ & $180^{\mathrm{bc}}$ & $2758^{c}$ & 1.38 \\
\hline Pseudomonas stutzeri & $294^{c}$ & $2073^{b}$ & $163^{d}$ & $310^{d}$ & $249^{d}$ & $2485^{b}$ & 1.24 \\
\hline Mixture & $324^{d}$ & $2177^{c}$ & $211^{\mathrm{e}}$ & $323^{\text {ed }}$ & $310^{\mathrm{e}}$ & $2698^{c}$ & 1.34 \\
\hline Micronema & $202^{b}$ & $2550^{e}$ & $134^{c}$ & $368^{9}$ & $167^{b}$ & $2851^{d}$ & 1.42 \\
\hline Mocap15\% & $96^{a}$ & $303^{a}$ & $33^{\mathrm{a}}$ & $80^{a}$ & $58^{a}$ & $394^{\mathrm{a}}$ & 0.196 \\
\hline Control & $1217^{f}$ & $9515^{h}$ & $681^{h}$ & $721^{\mathrm{h}}$ & $913^{9}$ & $11109^{h}$ & 5.55 \\
\hline LSD at 0.05 & 22.895 & 85.28 & 13.948 & 17.452 & 14.582 & 90.213 & \\
\hline
\end{tabular}

In each column, means followed by the same letters did not differ significantly at $p \leq 0.05$ according to Duncan's multiple range test $F P$ final population included number of juveniles in soil +egg masses + females

$R B$ rate of buildup, $(\mathrm{Pf} / \mathrm{Pi})$ where $\mathrm{Pf}$ is the final population/initial population 
Table 5 Plant growth parameters of eggplant affected by Meloidogyne incognita and treated by the selected bacterial isolates under greenhouse conditions

\begin{tabular}{|c|c|c|c|c|c|}
\hline Treatments & Shoot length $(\mathrm{cm})$ & Shoot fresh weight (g) & Shoot dry weight (g) & Root length $(\mathrm{cm})$ & Root fresh weight $(\mathrm{g})$ \\
\hline Paenibacillus amylolyticus & $47.3^{\mathrm{ab}}$ & $21.87^{\mathrm{bc}}$ & $2.9^{\mathrm{b}}$ & $20^{\mathrm{ab}}$ & $2.86^{\mathrm{cd}}$ \\
\hline Brevibacillus agri & $43.67^{\mathrm{bc}}$ & $18.64^{\text {de }}$ & $2.22^{\mathrm{cd}}$ & $16.67^{b c}$ & $3.09^{\mathrm{bcd}}$ \\
\hline Gluconobacter frateurii & $47.9^{\mathrm{a}}$ & $27.24^{\mathrm{a}}$ & $3.53^{\mathrm{a}}$ & $23.67^{\mathrm{a}}$ & $4.43^{\mathrm{a}}$ \\
\hline Beijerinkia mobilis & $44^{\mathrm{abc}}$ & $16.41^{\mathrm{e}}$ & $2.15^{\mathrm{cd}}$ & $18^{\mathrm{bc}}$ & $2.65^{d}$ \\
\hline Achromobacter aloeverae & $45.67^{\mathrm{abc}}$ & $24.65^{\mathrm{ab}}$ & $2.48^{c}$ & $16^{\mathrm{cd}}$ & $4.34^{\mathrm{a}}$ \\
\hline Pseudomonas stutzeri & $43.33^{c}$ & $25.61^{\mathrm{a}}$ & $2.9^{\mathrm{b}}$ & $17^{\mathrm{bc}}$ & $3.68^{\mathrm{b}}$ \\
\hline Mixture & $42^{c}$ & $21.42^{c d}$ & $2.98^{\mathrm{b}}$ & $17.33^{\mathrm{bc}}$ & $3.29^{b c}$ \\
\hline Micronema & $36^{d}$ & $13.33^{f}$ & $1.5^{\mathrm{e}}$ & $12.33^{\text {def }}$ & $2.57^{d}$ \\
\hline Mocap15\% & $35.33^{d}$ & $12.42^{\mathrm{fg}}$ & $1.21^{\mathrm{ef}}$ & $12^{e f}$ & $1.9^{\mathrm{e}}$ \\
\hline Healthy plant & $40^{c}$ & $16.37^{\mathrm{e}}$ & $2.07^{d}$ & $14.33^{\text {cde }}$ & $2.87^{\mathrm{cd}}$ \\
\hline Infected plant & $34.67^{d}$ & $10.1^{9}$ & $1.1^{f}$ & $10.33^{f}$ & $1.6^{\mathrm{e}}$ \\
\hline LSD at 0.05 & 3.9987 & 2.812 & 0.3709 & 3.72 & 0.59 \\
\hline
\end{tabular}

In each column, means followed by the same letters did not differ significantly at $(p \leq 0.05)$ according to Duncan's multiple range test

Effect of nematode infection and application of a biocontrol agent or pathogens on total microbial count (TMC) in eggplant rhizosphere

Microbial density as affected by nematode infection and application of pathogens were shown in Fig. 4. Results indicated that TMC was higher by the application of the bacterial isolates than that obtained under the application of nematicide. The highest increment in TMC was recorded in rhizosphere of plants treated with $B$. mobilis $\left(136 \times 10^{4} \mathrm{cfu} / \mathrm{g}\right.$ dry soil), followed by $A$. aloeverae and P. amylolyticus (123.7 and $117.67 \times 10^{4} \mathrm{cfu} / \mathrm{g}$ dry soil), respectively. The highest population of the rhizosphere soil in the treated plots may be due to the production of different bioactive substances by the bacterial isolates which can ultimately improve plant defense response or antagonize soil nematodes (Jiang et al. 2018).

\section{Conclusion}

Obtained results proved the effectiveness of the 6 bacterial isolates against the root-knot nematode ( $M$. incognita) under in vitro and under greenhouse conditions. The tested microorganisms significantly reduced the average number of galls, females, number of J2s, final population, and finally the rate of build-up. In addition, the bacterial isolates enhanced eggplant growth and microbial populations in rhizosphere soil.

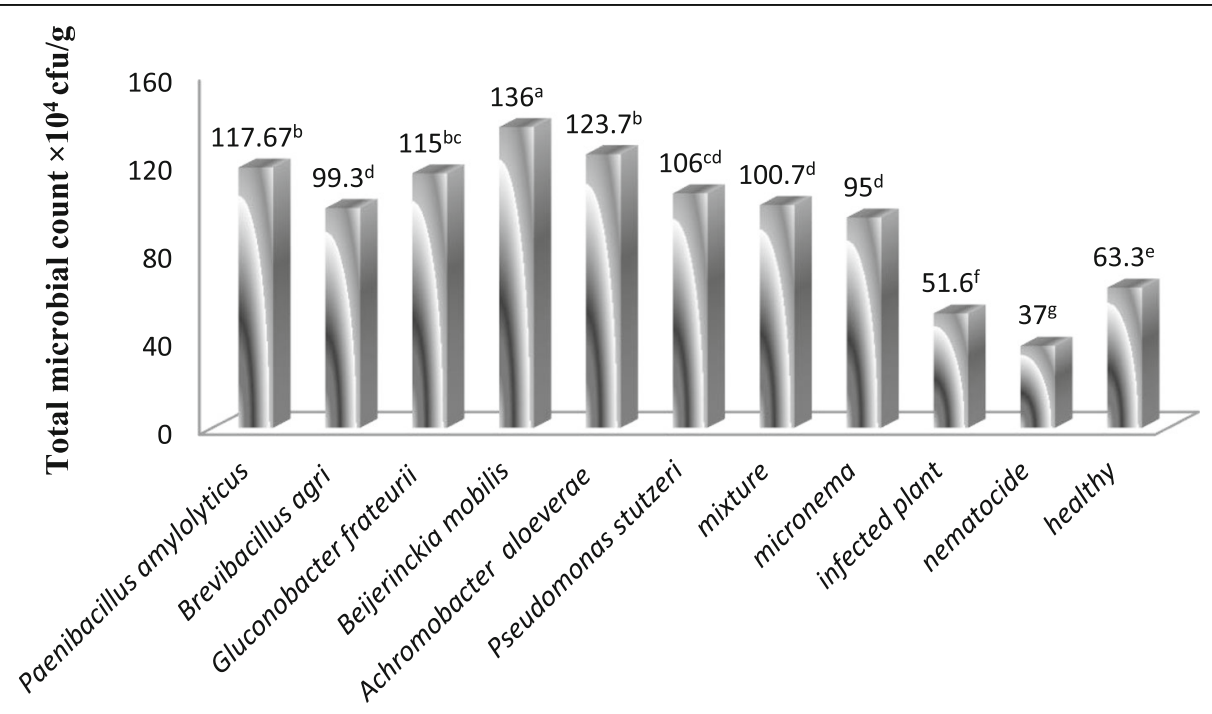

Fig. 4 Effect of nematode infestation and application of bioagent on total microbial count in eggplant rhizosphere. LSD at 0.05 is 11.01 


\section{Abbreviations}

PGPR: Plant growth-promoting rhizobacteria; NA: Nutrient agar; cfu: Colonyforming unit; J2: Second juvenile; DNA: Deoxyribonucleic acid; PCR: Polymerase chain reaction; HCN: Hydrogen cyanide; FP: Final population; RB: Rate of buildup; TMC: Total microbial count; ANOVA: Analysis of variance

\section{Acknowledgements}

Not applicable

\section{Authors' contributions}

GMA and RY were responsible for methodology, investigation, and manuscript writing. RY made the statistical analysis and revised the manuscript. Both authors read and approved the final manuscript.

\section{Funding}

Not applicable

\section{Availability of data and materials}

All data generated or analyzed during this study are included in this manuscript.

\section{Ethics approval and consent to participate}

Not applicable

\section{Consent for publication}

Not applicable

\section{Competing interests}

The authors declare that they have no competing interests.

\section{Author details}

'Plant Protection Department, Desert Research Center, El-Matariya, Cairo, Egypt. ${ }^{2}$ Fertility and Soil Microbiology Department, Water Resources and Desert Soils Division, Desert Research Center, El-Matariya, Cairo 11753, Egypt.

Received: 9 September 2020 Accepted: 6 November 2020

Published online: 23 November 2020

\section{References}

Abbott WS (1925) A method for computing the effectiveness of insecticides. J Econ Ent 18:265-267

Abd-Elgawad MM, Kabeil SA (2012) Biological control of Meloidogyne incognita by Trichoderma harzianum and Serratia marcescens and their related enzymatic changes in tomato roots. Afr J Biotechnol. 11:16247-16252

Abd-Elgawad MMM (2014) Yield losses by phytonematodes: challenges and opportunities with special reference to Egypt. Egypt J Agronematol 13(1):75-

Ahmed S (2017) Seed bacterization with Pseudomonas isolates against wheat cyst nematode (Heterodera avenae). Bangladesh J. Bot. 46(3):995-1000

Allen J (2004) Biology and management of soybean cyst nematode. Marceline: Schmitt \& Associates of Marceline 11:60-66

Apine OA, Jadhav JP (2011) Optimization of medium for indole-3-acetic acid production using Pantoea agglomerans strain PVM. J appl microbiol 110(5): $1235-1244$

Bakker AW, Schippers B (1987) Microbial cyanide production in the rhizosphere in relation to potato yield reduction and Pseudomonas spp. mediated plant growth stimulation. Soil Biol Biochem 19:451-457

Bakr RA, Mahdy ME, Mousa EM (2011) A survey of root-knot and citrus nematodes in some new reclaimed lands in Egypt. Pak. J. Nematol 29(2): $165-170$

Batool H, Fatima N, Hira K, Sultana V, Ara J, Ehteshamul-Haque S (2013) Role of fluorescent Pseudomonas associated with root nodules of soybean in suppressing the root rotting fungi and root knot nematode of soybean in soil amended with seeds of Vernonia antihelmenthica. Intr J Biol Res 1:73-79

Cetintas R, Kusek M, Fateh SA (2018) Effect of some plant growth-promoting rhizobacteria strains on root-knot nematode, Meloidogyne incognita, on tomatoes. Egypt J Biol Pest Control 28(1):7

El-Eslamboly AASA, Abd El-Wanis MM, Amin AW (2019) Algal application as a biological control method of root-knot nematode Meloidogyne incognita on cucumber under protected culture conditions and its impact on yield and fruit quality. Egypt J Biol Pest Control 29(1):18

Gheysen G, Mitchum M (2019) Phytoparasitic nematode control of plant hormone pathways. Plant physiol 179(4):1212-1226

Gordon R, Haynes WC, Pang CH-N (1973) The genus Bacillus. Agriculture Handbook no. 427. US Department of Agriculture, Washington, DC

Hall TA (1999) A user-friendly biological sequence alignment editor and analysis program for Windows TM. Bioedit Version, 7. 41:95-98.

Ishikawa J, Tsuchizaki N, Yoshida M, Ishiyama D, Hotta K (2000) Colony PCR for detection of specific DNA sequences in actinomycetes. Actinomycetol. 14:1-

Jiang CH, Fang W, Yu ZY (2014) Study on screening and antagonistic mechanisms of Bacillus amyloliquefaciens54 against bacterial fruit blotch (BFB) caused by Acidovorax avenae subsp. citrulli. Microbiol Res 170:95-104

Jiang CH, Xie P, Li K, Xie YS, Chen LJ, Wang JS, Xu Q, Guo JH (2018) Evaluation of root-knot nematode disease control and plant growth promotion potential of biofertilizer Ning shield on Trichosanthes kirilowii in the field. Braz J Microbiol 49(2):232-239

Liu F, Liu H, Zhou H, Dong Z, Bai X, Bai P, Oiao J (2014) Isolation and characterization of phosphate-solubilizing bacteria from betel nut (Areca catechu) and their effects on plant growth and phosphorus mobilization in tropical soils. Biol Fertil Soils 50:927-937

Luc M, Sikora RA, Bridge J (2005) Plant parasitic nematodes in subtropical and tropical agriculture, 2nd edn. CAB International, Willingford, U.K., 871 pp

Lucas JA, García-Cristobal J, Bonilla A, Ramos B, Gutierrez-Manero J (2014) Beneficial rhizobacteria from rice rhizosphere confers high protection against biotic and abiotic stress inducing systemic resistance in rice seedlings. Plant Physiol Biochem 82:44-53

Moens M, Perry R (2009) Meloidogyne species: a diverse group of novel and important plant parasites. In: Perry RN, Moens M, Starr JL (eds) Root-knot nematodes. CABI Publishing, Wallingford, pp 1-17

Murthy N, Bleakley B (2012) Simplified method of preparing colloidal chitin used for screening of chitinase-producing microorganisms. Internet J Microbiol 10(2):e2bc3

Nicol JM (2002) Important nematode pests. Bread wheat: Improvement and production, Rome, Italy, FAO plant production and protection series:345-366

Norton DC (1978) Ecollogy of plant parasitic nematodes Jon Willeg and Soms. New York, p 238

Pokhrel B, Pandeya A, Gurung S, Bista G, Kande S, Kandel RC, Magar RT (2014) Screening and optimization of extra cellular protease from bacteria isolated from sewage. European J Btechnol Biosci 2(1):46-49

Rashid Ml, Mujawar LH, Shahzad T, Almeelbi T, Ismail IM, Oves M (2016) Bacteria and fungi can contribute to nutrients bioavailability and aggregate formation in degraded soils. Microbiol. Res 183:26-41

Reeves M, Pine L, Neilands JB, Bullows A (1983) Absence of siderophore activity in Legionella sp. grown in iron deficient media. J. BacterioL 154:324-329

Saitou N, Nei M (1987) The neighbor joining method: a new method of constructing phylogenetic trees. Mol Biol Evol 4:406-425

Schneider P, Orelli O (1947) Entomologisches praktikum. Aarau Verlag. H. R. Sauerla. nder Co., 237

Schneider SM, Rosskopf EN, Leesch JG, Chellemi DO, Bull CT, Mazzola M (2003) Research on alternatives to methyl bromide: pre-plant and post-harvest. Pest Manag Sci 59:814-826

Sharma SB, Mohiuddin M, Jain KC, Remanandan P (1994) Reaction of pigeonpea cultivars and germplasm accessions to the root-knot nematode, Meloidogyne javanica. J nematol 26(4S):644

Soliman GM, Ameen HH, Abdel-Aziz SM, El-Sayed GM (2019) In vitro evaluation of some isolated bacteria against the plant parasite nematode Meloidogyne incognita. Bul. Nat. Res Cent 43(1):171

Southey JF (1970) Laboratory methods for work with plant and soil nematodes. Tech. Bull 2:148

Taylor AA, Dropkin VH, Martin GC (1955) Perennial pattern of root nematodes. Phtopathol (45):26-34

Tharshani N, Sivapalan A (2009) Eco-friendly management of tomato root-knot nematode (Meloidogyne spp.) in calci- red yellow latasol: environment Srilanka blog. Phytopathol 91:681-693

Timper P (2014) Conserving and enhancing biological control of nematodes. J Nematol 46(2):75-89

Tran TPH, Wang SL, Nguyen VB, Tran DM, Nguyen DS, Nguyen AD (2019) Study of novel endophytic bacteria for biocontrol of black pepper root-knot nematodes in the Central Highlands of Vietnam. Agrono 9(11):714 
Trudgill DL, Blok VC (2001) Apomictic, polyphagous root-knot nematodes: exceptionally successful and damaging biotrophic root pathogens. Annu Rev Phytopathol 39:53-77

Vaidya RJ, Shah IM, Vyas PR, Chhatpar HS (2001) Production of chitinase and its optimization from a novel isolate Alcaligenes xylosoxidans: potential in antifungal biocontrol. World J Microbiol Biotechnol 17:691-696

Wang SL, Chang WT (1997) Purification and characterization of two bifunctional chitinases/lysozymes extracellularly produced by Pseudomonas aeruginosa K-187 in a shrimp and crab shell powder medium. Appl. Environ. Microbiol 63(2):380-386

Watanabe FS, Olsen SR (1965) Test of an ascorbic acid method for determining phosphorus in water and $\mathrm{NaHCO}_{3}$ extracts from soil 1. Soil Sci Soc Am J 29(6):677-678

\section{Publisher's Note}

Springer Nature remains neutral with regard to jurisdictional claims in published maps and institutional affiliations.

\section{Submit your manuscript to a SpringerOpen ${ }^{\odot}$ journal and benefit from:}

- Convenient online submission

- Rigorous peer review

- Open access: articles freely available online

- High visibility within the field

- Retaining the copyright to your article

Submit your next manuscript at $\boldsymbol{\nabla}$ springeropen.com 